Семененко В. М., к.т.н, с.н.с.;

Лобко М. М., к.військ.н., доцент;

Кириченко С. О., к.військ.н.;

Овчаренко С. М.

Центр воєнно-стратегічних досліджень Національного університету оборони України імені Івана Черняховського, Київ

\title{
Аналіз і шляхи удосконалення територіальної оборони України
}

Резюме. Проведено аналіз проблем формування і завчасної підготовки сил територіальної оборони та керівництва ними в сучасних умовах.

Ключові слова: система територіальної оборони; сили територіальної оборони; керівництво силами територіальної оборони; спроможності сил територіальної оборони; сектор безпеки і оборони.

Постановка проблеми. Збройна агресія Російської Федерації проти України, ведення ії у новій формі - збройного конфлікту гібридного характеру, потребує принципово нових поглядів i підходів до розв'язання проблем оборони держави. Одним із важливих шляхів підвищення обороноздатності України $є$ підвищення спроможностей системи територіальної оборони (TpO).

Дослідження систем ТрО країн світу (табл. 1) показує, що підвищення обороноздатності країни завдяки системам TpO використовує переважна їх більшість [2].

Таблиця 1

Системи територіальної оборони

\begin{tabular}{|c|c|c|}
\hline Вид & Визначення & Де застосовусться, суть \\
\hline I & $\begin{array}{l}\text { Комплекс державних і воєнних заходів, } \\
\text { який проводяться для безпосередньої оборони } \\
\text { території держави та підтримки на своїй } \\
\text { території бойових дій військ, які входять до } \\
\text { складу воєнно-політичного блоку НАТО }\end{array}$ & $\begin{array}{l}\text { У більшості країн-членів НАТО (США, ФРН, Велика } \\
\text { Британія тощо) ЗС виконують завдання захисту національних } \\
\text { інтересів у складі об'єднаних сил або самостійно. } \\
\text { Для оборони національної території застосовуються сили } \\
\text { ТрО. ЗС можуть залучатися до оборони території, якщо } \\
\text { виконання таких завдань не впливає на виконання заходів } \\
\text { оборони держави }\end{array}$ \\
\hline II & $\begin{array}{l}\text { Комплекс державних і воєнних заходів, } \\
\text { спрямованих на підтримку та забезпечення } \\
\text { бойових дій } 3 \mathrm{C}\end{array}$ & $\begin{array}{l}\text { Система застосовувалась В’єтнамом у війні зі США. Нині } \\
\text { планується до застосування в деяких пострадянських країнах. } \\
\text { Сили ТрО застосовуються для охорони важливих об'єктів } \\
\text { (зокрема, військових), посилення охорони кордону, оборони } \\
\text { населених пунктів, участі в протидиверсійних операціях та } \\
\text { ведені бойових дій в тилу агресора “партизанськими” } \\
\text { способами. } \\
\text { 3С застосовуються лише для оборони держави, а сили } \\
\text { ТрО - для підтримки та всебічного забезпечення 3С }\end{array}$ \\
\hline III & $\begin{array}{l}\text { Комплекс державних заходів, які } \\
\text { здійснюються в регіонах, де немає регулярних } \\
\text { військ, і спрямовуються на координацію } \\
\text { управління діяльністю місцевих органів } \\
\text { державної влади, органів військового } \\
\text { управління, правоохоронних органів і сил } \\
\text { цивільного захисту населення для підтримки } \\
\text { правового режиму воєнного стану, організації } \\
\text { протидії противнику, ліквідації наслідків } \\
\text { катастроф і застосованих противником засобів } \\
\text { масового ураження }\end{array}$ & $\begin{array}{l}\text { Система була організована в СРСР. } \\
\text { За змістом схожа але масштабніша, яка формується в } \\
\text { країнах Азії (Китай, Північна Корея тощо); до ТрО } \\
\text { залучається все населення країни. У мирний час } \\
\text { запроваджується обов'язкова військова підготовка. } \\
\text { Управління системою покладалося на командування } \\
\text { військового округу воєнного часу. } \\
\text { Для підсилення військ ТрО з інших військових округів } \\
\text { можуть передаватися регулярні війська - частини } \\
\text { Сухопутних військ, авіація, сили ППО, а під час оборони } \\
\text { морського узбережжя - військові кораблі. } \\
\text { Основні угруповання ЗС залучаються до захисту } \\
\text { національних інтересів за межами національних кордонів. } \\
\text { Завдання ТрО покладаються на сили ТрО та військові } \\
\text { частини, які спеціально виділені для підсилення формувань } \\
\text { ТрО. }\end{array}$ \\
\hline
\end{tabular}


Розвиток поглядів на організацію та ведення територіальної оборони в кожній країні здійснюється 3 урахуванням геостратегічного положення, розвитку економіки, інфраструктури тощо. Наприклад, у Польщі війська територіальної оборони входять до складу сухопутних військ, в Угорщині війська (захисту тилу) складаються 3 військових частин центрального та обласного підпорядкування. Останні 3 них розгортаються лише у загрозливі періоди. У Румунії сили територіальної оборони створюються тільки під час війни.

У сучасних умовах, коли рівень загроз повномасштабної агресії Росії проти України значно зростає, в Україні є потреба вдосконалити систему $\mathrm{TpO} 3$ урахуванням активного застосування методів гібридної війни, що $\epsilon$ ключовим пріоритетом і одним 3 основних завдань, визначених чинною Стратегією національної безпеки України (п. 4.3) [1].

Досвід зарубіжних країн свідчить про те, що утримання підрозділів ТрО за собівартістю значно дешевше ніж утримання регулярних військ. Зокрема, в США утримання сил ТрО в 6 разів дешевше ніж утримання армійських підрозділів, а в Швеції та Німеччині - у 10 разів [3, 7]. В Україні формування та розвиток системи ТрО здійснюється найбільш дешевим i найменш ефективним шляхом.

Незважаючи на чотири роки, протягом яких продовжується російська агресія, донині в Україні ще завчасно вести мову про ТрО як про цілісну систему, здатну виконувати завдання 3 достатнім ступенем ефективності (рис. 1).

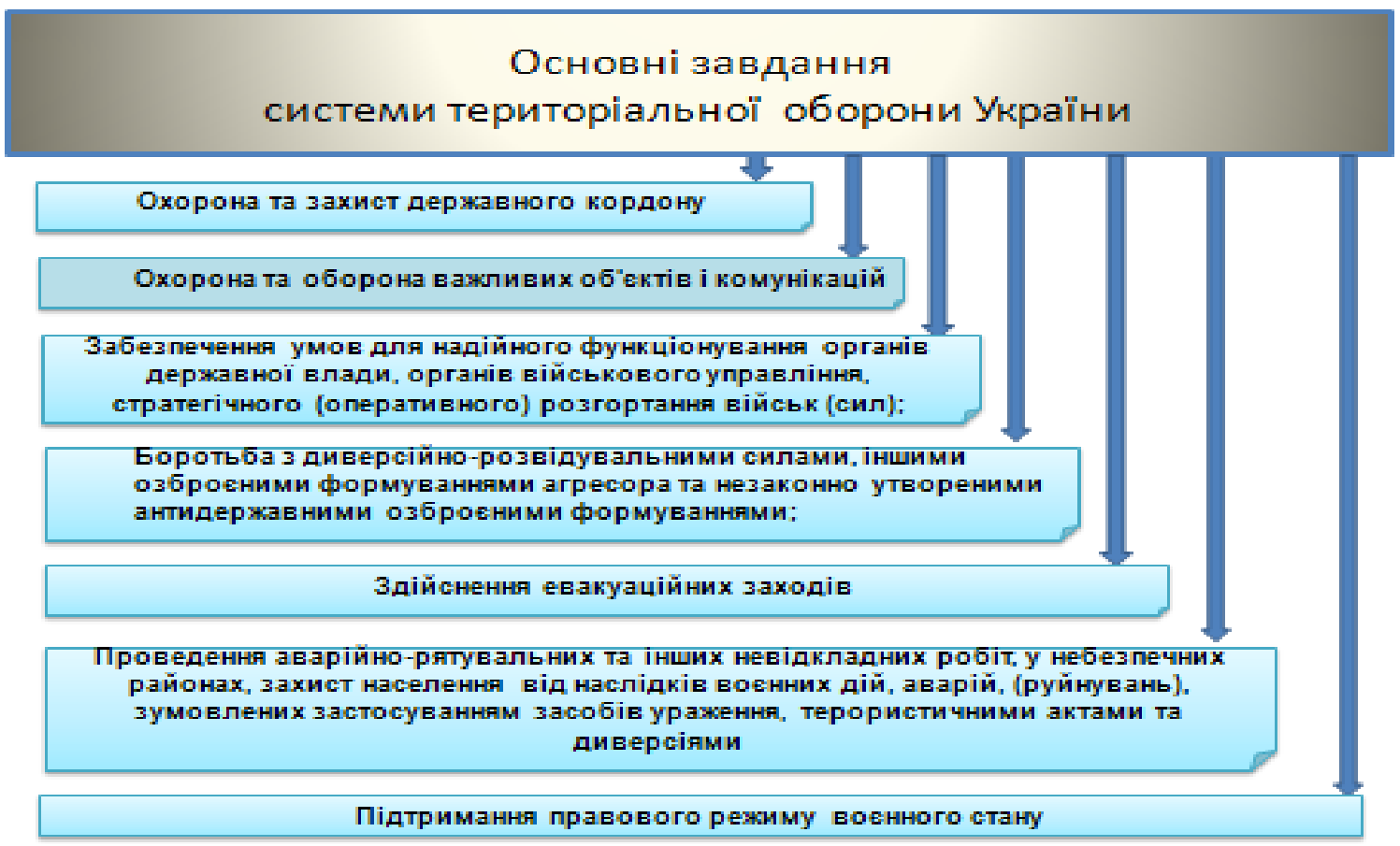

Рис. 1. Основні завдання, що покладаються на систему ТрО

Аналіз показує, що єдина система ТрО держави остаточно ще не сформована і має низку проблем, які потребують розв'язання. Вони стосуються як законодавчого внормування, так і формування, комплектування, розміщення, підготовки та застосування сил $\mathrm{TpO}$ в сучасних умовах, починаючи від завчасної їх підготовки у мирний час до виконання завдань в особливий період.

Як свідчить досвід локальних війн i збройних конфліктів другої половини минулого та нинішнього століть, проведення АТО на Сході України, підготовлені підрозділи ТрО можуть значно збільшити обсяги завдань, що на них покладаються, та надавати значну допомогу регулярним військам, зокрема, щодо: прикриття флангів військових угруповань; контролю комунікацій, що використовуються військами (силами); утримання районів території на менш важливих напрямках; посилення охорони державного кордону України тощо. Тому питання підготовки та розвитку системи ТрО в Україні $\epsilon$ одним із пріоритетних завдань зміцнення обороноздатності держави.

Система ТрО може сприяти істотному спрощенню та здешевленню всебічного забезпечення власних підрозділів, оскільки матиме можливості використовувати місцеві ресурси та матеріально-технічні запаси місцевих баз і складів, як основні джерела забезпечення.

Аналіз останніх досліджень і публікацій. 3 початку створення системи $\mathrm{TpO}$ в Україні до сьогодні в теоретичному плані вона набула 
значних змін. Особливо це стосується періоду, який почався після анексії Криму Росією та розв'язання нею на Сході України збройного конфлікту. У новій редакції ст. 18 Закону України "Про оборону України" натепер визначені нові підходи до ТрО. Проте в чинному Положенні суттєва частина вимог зазначеного закону не врахована. Не визначені повноваження регіональних органів влади та місцевого самоврядування 3 питань організації і ведення $\mathrm{TpO}$, не уточнені їх завдання. Відсутні й завдання щодо вдосконалення системи управління ТрО. Доцільно також розширити коло суб'єктів забезпечення цієї важливої сфери діяльності. До них варто залучити відповідні органи державної влади, місцевого самоврядування та військового управління, правоохоронні органи, ради оборони областей, що створюються в особливий період, війська (сили) та засоби, що залучаються до виконання завдань ТpO.

До того ж варто відновити функціонування спеціальних формувань (автомобільні, авіаційні, водні, залізничні, медичні тощо), які, відповідно до ст.1 Закону України "Про мобілізаційну підготовку та мобілізацію”, мають утворюватися в мирний час підприємствами, установами i організаціями, а після відповідної підготовки, передаватися у встановленому порядку до Збройних Сил чи інших військових формувань.

Потребує активізації в цьому контексті і воєнна наука, оскільки останні наукові публікації з цих проблем видані у 2007 - 2015 роках [3-9]. Вони вже не повною мірою відповідають наявним завданням і потребам сьогодення.

Нині у теоретичному та правовому плані надзвичайно важливо остаточно визначитись із поняттям “територіальна оборона України”, ii системою, завданнями та періодами функціонування чи реалізації в сучасних умовах, повноваженнями органів державної влади, місцевого самоврядування та органів військового управління до переведення, при необхідності, 3 мирного на воєнний стан та виконання визначених завдань в особливий період.

Метою статті $\epsilon$ аналіз наявних проблем $\mathrm{TpO}$ та пошук ефективних шляхів їх подолання для підвищення ефективності обороноздатності держави в сучасних умовах.

Викладення основного матеріалу. Досвід розвитку та функціонування системи $\mathrm{TpO}$ в Україні у 2014 році свідчить, що визначені нормативні показники щодо формування та підготовки не були реалізовані в належному обсязі. Навіть часткове розгортання системи ТрО в окремо визначених зонах відбувалося значно пізніше встановлених часових показників.
В останніх редакціях нормативно-правових актів не враховано визначене у Воєнній доктрині України 2004 року (п. 10 б) поняття “"загрозливий період”. Однак потреба завчасної підготовки системи $\mathrm{TpO}$ на загрозливий період мала би налаштовувати iii так само на максимально швидкий перехід до дій у разі введення воєнного стану чи особливого періоду. Практично ніяких завдань не визначено суб' єктам зі створення системи ТрО у мирний час.

3 огляду на ці недоліки, найдоцільнішим шляхом розвитку системи ТрО нині було б розроблення та прийняття Закону України "Про територіальну оборону” та вдосконалення чинного Положення про TpO, у якому бажано визначити, яку систему ТрО слід розвивати в Україні у сучасних безпекових умовах, у тому числі в мирний час, “загрозливий період” чи інших кризових ситуаціях, засади iї функціонування, порядок організації та підготовки тощо. Зокрема, основні заходи підготовки територіальної оборони мають здійснюватися, не лише в особливий період, як визначено Законом України "Про оборону України" (ст. 18), а завчасно як у мирний час, так і з виникненням кризової ситуації, а саме у “загрозливий період" та у разі початку війни (збройного конфлікту).

Підготовка має складатись із завчасної та безпосередньої. Завчасну підготовку доцільно здійснювати згідно із затвердженими планами, які мають включати: планування ТрО, організаторську роботу; підготовку системи та органів управління; підготовку військ (сил) та засобів і ресурсів та вирішення питань завчасної їх підготовки до ведення ТрО тощо.

Система комплектування військових частин та підрозділів ТрО особовим складом так само залишається невпорядкованою, що також $\epsilon$ проблемоюна сьогодення. Якість його підбору не повною мірою відповідає сучасним вимогам. Наприклад, переважна більшість офіцерів підрозділів не проходили військової служби у ЗС України.

На цей час в Україні військові частини та підрозділи ТрО комплектуються переважно на основі мобілізації. Законодавчо не передбачене залучення до складу сил ТрО добровольців. Поза увагою військових комісаріатів залишається питання спроможностей громадських організацій патріотичного налаштування допомагати цьому процесу. Така практика використовується лише в окремих прикордонних районах. Органи місцевої влади та місцевого самоврядування недостатньо приділяють уваги i не несуть належної відповідальності за підбір особового складу до сил $\mathrm{TpO}$ в своїй зоні чи районі відповідальності. Недостатня увага приділяється i військово- 
патріотичному вихованню, не використовується позитивний вплив засобів масової інформації, а також на недостатньому рівні проводиться протидія російській пропаганді.

Практика розгортання підрозділів $\mathrm{TpO}$ у 2014-2015 роках свідчить про те, що вже в мирний час вони потребують нових підходів до уточнення завдань щодо створення військового резерву людських ресурсів, призначенного для комплектування органів, загонів, підрозділів, які беруть участь у виконанні завдань територіальної оборони та організації підготовки особового складу, який призначений для комплектування підрозділів ТрО.

Результати узагальнення досвіду формування системи ТрО та напрями, за якими здійснюється завчасна підготовка сил ТрО у деяких країнах світу, наведено в табл. 2.

Таблиця 2

Основні елементи сил ТрО та напрями їх завчасної підготовки в краӥнах світу

\begin{tabular}{|c|c|c|c|c|c|c|c|c|c|c|}
\hline \multirow[b]{2}{*}{ 疍 } & \multirow[b]{2}{*}{ 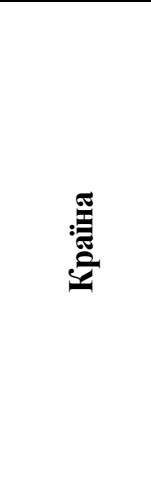 } & \multirow[b]{2}{*}{ 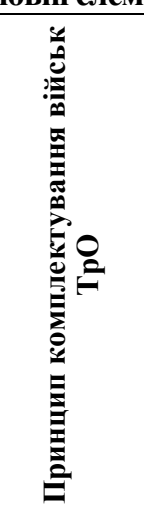 } & \multirow[b]{2}{*}{ 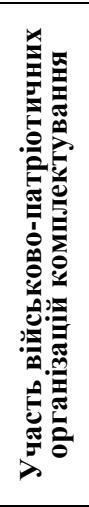 } & \multirow[b]{2}{*}{ 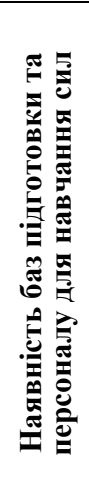 } & \multirow[b]{2}{*}{ 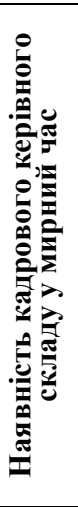 } & \multirow[b]{2}{*}{ 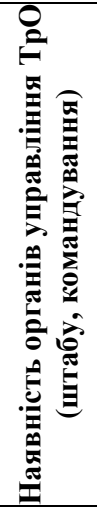 } & \multirow[b]{2}{*}{ 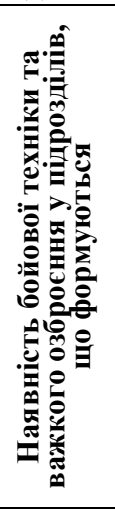 } & \multirow[b]{2}{*}{ 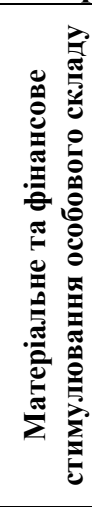 } & \multicolumn{2}{|c|}{$\begin{array}{c}\text { Основні завдання } \\
\text { сил ТрО }\end{array}$} \\
\hline & & & & & & & & & 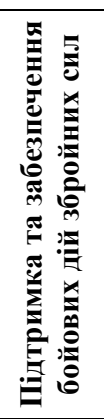 & 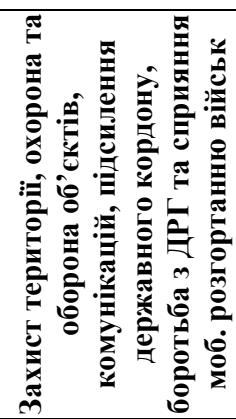 \\
\hline 1 & США & Добров. & $\begin{array}{c}- \\
\end{array}$ & + & + & + & + & & + & + \\
\hline 2 & Канада & Добров. & - & + & + & - & - & + & + & \\
\hline 3 & Німеччина & Призов & - & + & + & + & + & & + & + \\
\hline 4 & Туреччина & Змішана & - & + & + & + & + & & + & + \\
\hline 5 & Швеція & Добров. & + & + & + & - & - & & & + \\
\hline 6 & Польща & Добров. & + & + & + & - & + & + & + & + \\
\hline 7 & Латвія & Добров. & + & + & - & - & - & + & + & + \\
\hline 8 & Естонія & Добров. & + & + & - & - & - & & + & + \\
\hline 9 & Чехія & Призов & + & + & + & + & - & & + & - \\
\hline 10 & Білорусь & Призов & - & - & - & - & - & - & + & + \\
\hline 11 & Казахстан & Призов & - & - & - & - & - & - & + & + \\
\hline 12 & Україна & Призов & - & - & - & - & - & - & - & + \\
\hline
\end{tabular}

Аналіз досвіду формування системи ТрО в різних країнах світу, в порівнянні з Україною, дає змогу дійти висновку, що відсутність основних елементів сил ТрО та напрямів їх завчасної підготовки в Україні негативно впливає на створення та ефективне функціонування системи ТрО, яка б спромоглася в короткі строки розгорнутися та почати функціонування.

Для розв'язання зазначених проблем, з урахуванням досвіду зарубіжних країн, доцільно:

1) військове управління підрозділами ТрО покласти на кадрових офіцерів, які знаходяться на військовій службі, володіють сучасними знаннями і практикою дій військ (сил) у сучасних умовах, специфікою дій підрозділів ТрО та здатні у стислі терміни провести бойове злагодження цих підрозділів і приведення їх у готовність до виконання завдань;

2) набір особового складу до підрозділів ТрО здійснювати за змішаним принципом, залучаючи як добровольців, які виявили бажання служити у силах ТрО, так і підібраних військовими комісаріатами за участю відповідних органів СБУ та МВС громадян;

3) при формуванні підрозділів $\mathrm{TpO}$ доцільно взяти до уваги позитивний досвід прибалтійських держав і надавати перевагу членам військово-патріотичних організацій, діяльність яких спрямована на сприяння захисту батьківщини, що значно посилюватиме ефективності цієї роботи;

4) визначити статус військових частин і підрозділів ТрО у структурі ЗС України (у законодавстві й інших нормативно-правових документах вони не вказані);

5) вдосконалити на законодавчому рівні систему фінансового та материального заохочення тих осіб, які залучаються до підрозділів ТрО. Зокрема, в Республіці Польща, кожен військовозобов'язаний, який проходить підготовку у складі військ ТрО, щомісячно отримує 
додатково понад 160 євро, а у деяких інших країнах їм надають додаткові вихідні дні або збільшують термін щорічної оплачуваної відпустки. Додаткове фінансування цих заходів здійснюється завдяки як державному бюджету, так і місцевим бюджетам областей та районів.

Суттєвою проблемою, яка так само потребує вирішення в Україні, залишається завчасна підготовка особового складу підрозділів ТрО.

Висновок. Аналіз наявних проблем у системі ТрО України свідчить, що сучасна воєннополітична обстановка та інші.

загрозливі безпекові реалії сьогодення потребують термінового удосконалення законодавчої та нормативно-правової бази щодо створення та функціонування системи $\mathrm{TpO}$, пошуку нових шляхів та механізмів для підвищення ефективності іiі функціонування та швидкого впровадження у практику дій військ.

Напрямами подальших досліджень вважаємо: вдосконалити законодавство України щодо ТрО, визначити в ньому систему ТрО, як складову оборони України, iї організацію та завдання, визначити повноваження та завдання суб'єктів ТрО в мирний час, переглянути терміни готовності окремих елементів системи, інші необхідні елементи та порядок їх взаємодії під час підготовки та ведення ТрО для забезпечення ефективної оборони держави від агресора на всій iii території.

\section{СПИСОК ВИКОРИСТАНОЇ ЛІТЕРАТУРИ}

1. Стратегія національної безпеки України: затв. Указом Президента України від 26.05.2015

2. Сектор безпеки i оборони України : збірка наукових матеріалів. Київ, 2015. 174 с.

3. Територіальна оборона: практика і теорія: URL : http://www.ostanovkam.net/ index.php/ 26-ruv/ 324territorialnaya-oborona-praktika-i-teoriya

4. Грабчак В. І., Єфімов Г. В., Замана В. М. та ін. Воєнна організація, сектор безпеки, територіальна оборона України: державно-управлінський аспект: монографія. Львів, 2013. $372 \mathrm{c.}$

5. Фролов В. С., Романченко I. С., Палій В. В. Територіальна оборона України: якою їй бути? // Наука і оборона. 2007. № 1. С. 18-23.

6. Романченко I. С., Фролов В. С. Роль і місце територіальної оборони України в загальній системі оборони держави // Наука і оборона. 2009. № 1. C.36-39.

7. Романченко I. С., $\quad$ Фролов В. С., Палій В. В. Шляхи підвищення ефективності системи управління територіальною обороною України // Наука і оборона. 2009. № 4. С.6-11.

8. Саганюк Ф. В., Гуменюк В. В. Територіальна оборона - резерв посилення обороноздатності держави // Військо України. 2011. № 6. С. 15-17.

9. Саганюк Ф. В., Гуменюк В. В. Територіальна оборона: шляхи відродження // Оборонний вісник. 2011. № 3. С. 6-10.

№ 287/2015.

Стаття надійшла до редакції 24.05.2018

Семененко В. М., к.т.н, с.н.с.;

Лобко М. Н., к.воен.н., доцент;

Кириченко С. А., к.воен.н.;

Овчаренко С. Н.

Центр военно-стратегических исследований Национального университета обороны Украины имени Ивана Черняховского, Киев

\section{Анализ и пути совершенствования территориальной обороны Украины}

Резюме. Проведен анализ проблем формирования и заблаговременной подготовки сил территориальной обороны и управления ими в современных условиях.

Ключевые слова: система территориальной обороны; силы территориальной обороны; руководство силами территориальной обороны; возможности сил территориальной обороны; сектор безопасности и обороны.

\section{Semenenko, PhD (Technical), senior researcher;}

M. Lobko, PhD (Military), assistant professor;

S. Kirichenko, PhD (Military);

S. Ovcharenko

Center for Military and Strategic Studies of the National Defence University of Ukraine named after Ivan Cherniakhovskyi, Kyiv

Analysis and ways to improve territorial defence

Resume. The analysis of problems of formation and advance preparation of the forces of territorial defense and their management in modern conditions is carried out.

Keywords: territorial defense system; the forces of territorial defense; leadership of the territorial defense forces; the capabilities of territorial defense forces; sector of security and defense. 